\title{
The Paradigm of Progressive Judge's Decision and Its Contribution to Islamic Legal Reform in Indonesia
}

\author{
Suad Fikriawan ${ }^{1^{*}}$, Syamsul Anwar ${ }^{2}$, Misnen Ardiansyah ${ }^{3}$ \\ ${ }^{1 *}$ Institut Agama Islam Sunan Giri (INSURI) Ponorogo \\ Jl. Batoro Katong No. 32, Ronowijayan, Siman, Ponorogo \\ Email: suad.fikriawan@gmail.com \\ 2,3 Universitas Islam Negeri Sunan Kalijaga \\ Jl. Marsda Adisucipto, Caturtunggal, Sleman, Yogyakarta \\ Email: ${ }^{2} h s y a m s u l . a n w a r @ u i n-s u k a . a c . i d ;{ }^{3}$ misnen.ardy91@gmail.com
}

\begin{tabular}{llll} 
Submit & $: 13$ April 2021 & Diterima & $: 25$ Agustus 2021 \\
Revisi & $: 16$ November 2021 & Terbit & $: 1$ Desember 2021 \\
\hline
\end{tabular}

\begin{abstract}
The main issue to be discussed in this paper is how is the contribution of the Judge's ruling to legal reform in Indonesia? This study used the perspective of the School of Sociological Jurisprudence, mainly the philosophical mind of Roscoe Pound. The results of this study show that the effort to make a judge's ruling as a means of legal reform is a necessity. This can be realized through the progressive legal paradigm. The presence of a progressive legal paradigm is very important in order to give birth to a progressive type of judge who has a legal ruling that qualifies maturity of law. The product of a progressive judge's ruling is expected to become a jurisprudence that can be used as a reference in solving the next case so that judges will be able to make the law, not merely as a tool of social control as well as a tool of social engineering. These conceptions of legal function are essentially about to reveal that the nature of the law is dynamic rather than static. The legal philosophy of the sociological jurisprudence school offers a holistic understanding and a holistic view of the law, that is, the law applied must pay attention to the values, the living law, and the local wisdom of society. This holistic understanding of the law will ultimately be able to unify the law and society as its sociological basis.
\end{abstract}

Keywords: Sociological Jurisprudence, Judge's decision, Progressive law, Paradigm.

Abstrak: Pokok permasalahan yang dibahas dalam tulisan ini adalah bagaimana kontribusi putusan Hakim terhadap reformasi hukum di Indonesia? Kajian ini menggunakan perspektif mazhab Sociological Jurisprudence, terutama pemikiran filosofis Roscoe Pound. Hasil penelitian ini menunjukkan bahwa upaya menjadikan putusan hakim sebagai sarana pembaharuan hukum merupakan suatu keniscayaan. Hal ini dapat diwujudkan melalui paradigma hukum progresif. Kehadiran paradigma hukum progresif sangat penting guna melahirkan tipe hakim progresif yang memiliki putusan hukum yang memenuhi syarat kedewasaan hukum. Produk putusan hakim progresif diharapkan dapat menjadi yurisprudensi yang dapat dijadikan acuan dalam menyelesaikan perkara selanjutnya sehingga hakim mampu membuat undang-undang, tidak hanya sebagai alat kontrol sosial tetapi juga sebagai alat rekayasa sosial. Konsepsi fungsi hukum ini pada hakikatnya hendak mengungkapkan bahwa hakikat hukum itu dinamis daripada statis. Filosofi hukum mazhab sosiologi hukum menawarkan pemahaman yang holistik dan pandangan hukum yang holistik, yaitu hukum yang diterapkan harus memperhatikan 
nilai-nilai, hukum yang hidup, dan kearifan lokal masyarakat. Pemahaman hukum yang holistik ini pada akhirnya akan mampu menyatukan hukum dan masyarakat sebagai landasan sosiologisnya.

Kata kunci: Sociological Jurisprudence, Putusan Hakim, Hukum Progresif, Paradigma

\section{Introduction}

Indonesia is a country where the last few decades have been stricken by a major crisis, including the crisis in the field of law. The legal crisis in Indonesia is marked by the decline of moral integrity and professionalism of the law enforcement officials. ${ }^{1}$ The Supreme Court and the courts under it received a very strong spotlight from various circles who were dissatisfied by the decisions made and the conduct of court officials. ${ }^{2}$ In this context, it is necessary to have a judge who, in fact, as one of the law enforcement apparatus, who has integrity, honesty and strong determination to carry out legal reforms to create a great judiciary and restore the judicial implementing institution into an authoritative, professional, and accountable judiciary institution in line with the vision of the Supreme Court, realizing of a great Indonesian judicial body. ${ }^{3}$

The role of judge as an apparatus of judicial power in principle is none other than to carry out the functions of the judiciary. In performing this judicial function, judges must be fully aware that the principal duty of the judge is to enforce law and justice. ${ }^{4}$ In relation to this, Prof. Taverne, a Dutch legal expert, once stated that "with good law enforcement, even bad law will show about justice in the society". This is in line with the slogan posted in one of the courts in England which reads: "Give me a good judge, even I have a bad law in my hand". Bad law in this sense can still be improved while the character and behavior of judged, especially morals, is the most fundamental thing in law enforcement, so it must be firm, stable, and mature in the application of law and decision even if there is internal or external in its application. ${ }^{5}$ Therefore, the thing that the judge in law enforcement should consider is the aspect of his human resources as a law enforcement apparatus. Although legislation is complete, facilities and infrastructure are available, but will remain a crucial barrier when humans are inconsistent, have no integrity and morality, unprofessional, and have no honesty in enforcing law and justice.

Judges are required to have intellectuality, mastery of legislation and understand the social environment and legal values that live in society. Article 5 paragraph (1) of Law Number 48/2009 Jo. Article 22 Compilation of Islamic Law (KHI), affirms that judges shall explore, follow and understand the values of law and justice that live in society. ${ }^{6}$ The provision is in line with the view of the school of sociological jurisprudence, which states that the law made must pay attention to living law. ${ }^{7}$

1 Budi Agus Riswandi dan M. Syamsuddin, Hak Kekayaan Intelektual dan Budaya Hukum (Jakarta: Raja Grafindo, 2009$), 137$.

2 Satjipto Rahardjo, Penegakan Hukum Progresif (Jakarta: Penerbit Buku Kompas, 2010), 167-168.

3 Mahkamah Agung RI, Cetak Biru Pembaruan Peradilan 2010-2035 (Jakarta: MA RI, 2010), 13-14.

4 Richard A. Posner, "The Role of The Judge in The Twenty-First Century", Boston University Law Review, Vol. 86. (2006): 10491068.

5 Teguh Santoso, Gunarto, and Anis Anis Masdurohatun, "The Progressive Legal Theory and The Implementation of Law Enforcement By The The Law Enforcer (Police, Prosecutor, Judge)," The $3^{\text {rd }}$ Proceeding of Legal Development of Various Countries, Sultan Agung Islamic University, (Semarang: UNISSULA Press 2017), 100.

6 Undang-Undang Republik Indonesia Nomor 1 Tahun 1974 Tentang Perkawinan dan Kompilasi Hukum Islam (Bandung: Citra Umbara, 2007).

7 Richard Langone, "The Science of Sociological Jurisprudence as a Methodology For Legal Analysis," Touro Law Review, Vol. 17, No. 4, Art. 5, March (2015): 768-800. See also, Brian Z. Tamanaha, "The Third Pillar of Jurisprudence: Social Legal Theory," 
Therefore, a judge should not only be a mouthpiece of the law, but a judge must be professional in enforcing law and justice.

Based on the description above, this paper intends to discuss the judge's decision and its contribution to legal reform in Perspective of the Sociological Jurisprudence School. In the Sociological Jurisprudence School, of course there are many figures. This study, therefore, has largely confined itself to Roscoe Pound's legal philosophy as the main proponent of the Sociological Jurisprudence. ${ }^{8}$ The thought of Pound's legal philosophy is what the author wants to make perspective in this study. The main reason for using of this school as a perspective of this study is that the legal philosophy of the sociological jurisprudence school offers a holistic understanding and a holistic legal perspective, i.e. the applied law must pay attention to the values, living laws and local wisdom of society. This conception at the same time provides the basis of how urgency of interaction between law and society, the law must be compared to the community to meet the benefits of law and community welfare.

\section{The School of Sociological Jurisprudence: As A Progressive Law School}

\section{a. The Paradigm of Progressive Thinking in Deciding the Case}

The term paradigm was originally used in the world of science, mainly in the field of philosophy of science. In terminological terms, this term was developed by Thomas S. Kuhn in his book The Structure of Scientific Revolution. ${ }^{9}$ Paradigm is defined as basic assumptions or general theoretical assumptions. Paradigm, therefore, is a source of value, law, and methodology. In accordance with its position, the paradigm has a strategic function in building the framework of thinking and strategy of its application, so that each science has characteristic that is different from other science.${ }^{10}$ Science has a dynamic nature. This means that the theories that have been established, established, and acknowledged its existence in science can undergo change because of new findings obtained through the world of research. If so, then the scientist must return to basic assumptions or theoretical assumptions to examine the paradigm of science concerned. The term paradigm is increasingly growing, and can be used in many areas of life and science.

In law reasoning activities, both related to the subject as well as the object of reasoning, contains three dimensions. First, the ontological dimension, which is related to the nature of the law established. For example, is the law in this context defined as the principle of justice and truth, or law as the norm of positive law in the legal system, or law as social behavior in a macro and micro scale, etc. Second, the axiological dimension, the goal to be achieved by law. Related to this, for example what has been introduced by Gustav Radbruch through his thesis on "three basic values of law" include the value of certainty, justice and expediency. ${ }^{11}$ What is called Radbruch with the basic value of utility

William \& Mary Law Review, Vol. 56, No. 6, Art. 6 (2015): 2235-2277; also Harold P. Pareja, “Sociological Jurisprudence: It's History, Applications, And Trends," SDSSU Multidisciplinary Research Journal, Vo. 2 No. 1, Jan-June (2014): 61-69.

8 See e.g., James A. Gardner, "The Sociological Jurisprudence of Roscoe Pound (Part I)," Villanova Law Review, Vol. 7, No. 1, Art. 1 (1961): 1-26.

9 See Thomas S. Kuhn, The Structure of Scientific Revolution, 2nd Edition (Chicago: The University of Chicago Press, 1970). See also Kuhn, "The Structure of Scientific Revolution," International Encyclopedia of Unified Science, Vol. 2, No. 2 (1970).

10 Satjipto Rahardjo, Hukum dan Perubahan Sosial (Bandung: Alumni, 1979), 257.

${ }^{11}$ Gustav Radbruch, Legal Philosophy, (First Publ., 1932), trans. Kurt Wilk, in: The Legal Philosophy of Lask, Radbruch, and Dabin (Cambridge, Mass: Harvard University Press, 1950), 110. See also Erik Wolf, “Revolution or Evolution in Gustav Radbruch's Legal Philosophy”, Natural Law Forum, Art. 25 (1958): 1-23; also Irma Shioshivili, “General Antecedents of Philosophy by Gustav Radbruch," Bulletin of The Geogrian National Academy of Science, Vol. 11, No. 2 (2017): 128-135. 
established the law in terms of the larger social context. Thus, he was a pioneer for legal studies that concern the interaction between law and society. Third, the epistemological dimension. It is about the method or approach used by the legal subject (judge) in relation to its object. In the context of this epistemology, reasoning not only uses the ratio as the only modality that the subject (judge) uses in approaching the object of his study. There are other modalities beyond ratio, such as the senses and intuition (dzauq). It is recalled the subjects of the law (judges) are not entirely rational beings, but also ethical and political beings. ${ }^{12}$ Rational thinking in legal reasoning is required, but obviously this is not the only modality in legal reasoning. Almost all cases faced by judges are structured and patterned very complex. As a logical consequence, then legal reasoning should be intersected to moral reasoning. In this aspect, legal reasoning can be found. If legal reasoning is limited only to rational activity as is commonly known in the exact sciences, then as the implication of the primary function of judge as law enforcer on the one side, it will deny its function as law maker on the other side. This phenomenon can be felt in the Indonesian legal system that follows the civil law system. In such a position, the judge will be easily trapped in the tendency of the way of thinking of the flow model of legal positivism, even the positivism of the law. ${ }^{13}$

The quality of the judge's understanding of the philosophical and theoretical problems of a legal matter is still not enough. This is, as asserted above, because the influence of legal-positivism is still very dominant in mastering the judges' way of thinking in constructing a decision. In connection with this, Syamsudin said that there are two typologies of judge thinking paradigm in handling the case, they are positivistic type and non-positivistic type. The first paradigm shapes strongly emphasize the formal measures of rule text in understanding the truth of the law, while the second style elaborates the text of the rule of law with the social-cultural context that surrounds it. ${ }^{14}$

\section{b. The Legal Philosophy of Roscoe Pound}

Pound said that the main problem to which sociological jurists are addressing themselves today is to enable and to compel law-making, and interpretation and application of legal rules, to take more account, and more intelligent account, of the social facts upon which law must proceed and to which it is to be applied. ${ }^{15}$

In a formula, Pound even describes that the central task of modern thought concerning law is the task of social engineering to build a community structure in order to maximally achieve satisfaction of needs, and minimize collisions and waste. ${ }^{16}$ In his other work, In My Philosophy of Law, Pound also stated that law as in one sense a highly specialized form of social control in a developed politically organized society -a social control through the systematic and orderly application of the force of such a society. ${ }^{17}$ To pursue the concept of law in the social sphere, Pound offers several operational steps

12 Shidarta, "Filosofi Penalaran Hukum Hakim Konstitusi dalam Masa Transisi Konstitusionalitas", Jurnal Hukum Jentera, Edisi 11 tahun III, Januari-Maret (2006), 6.

13 Ibid., 8.

${ }^{14}$ Syamsudin, “Kecenderungan Paradigma Berpikir Hakim dalam Memutuskan Korupsi”, Jurnal Media Hukum Fakultas Hukum (terakreditasi), Universitas Muhamadiyah Yogyakarta (UMY), Desember (2008), 90-97.

15 See Pound, "The Scope and Purpose of Sociological Jurisprudence", in Ervin H. Pollack, Jurisprudence: Principles and Applications (The Ohio State University Press, 1979), 643.

16 This formula is expressed by Pound in his "Interpretations of Legal History", chapter 7; also Pound, An Introduction to the Philosophy, 85. See also e.g. R.W.M. Dias, Jurisprudence (London: Butterworths, 1976).

17 See Pound, "In My Philosophy of Law", in Ervin H. Pollack, Jurisprudence: Principles and Applications (The Ohio State University Press, 1979), 635. 
for the application of law in the judgment of a case. They are: (1) Finding the law, ascertaining which of the many rules in the legal system is to be applied, or, if none is applicable, reaching a rule for the cause (which may or may not stand as a rule for subsequent cases) on the basis of given materials in some way which the legal system points out; (2) interpreting the rule scope; (3) applying to the cause in hand the rule so found and interpreted. ${ }^{18}$ In the past these have been confused under the name of interpretation. It was assumed that the function of the judge consisted simply in interpreting an authoritatively given rule of wholly extra-judicial origin by an exact process of deducing its logically implied content and in mechanically applying the rule so given and interpreted.

With the process above, a judge will be able to apply the law well, not just taking not just taking obtained rules randomly. From these three operational steps it can be understood that in conception Pound judges not only apply the law to all cases handled. For the Pound the judge should be given a large space of discretion in applying the law and the rule of law is only a general rule for judges. Here it seems that Pound has provided a solution to the judge's creativity problem as a law-maker.

\section{Islamic Legal Reform through Jurisprudence}

\section{a. Significance of Judge's Decision}

It is no secret that the judge's decision is the crown of the judges. The verdict is a declaration of a judge as outlined in a written form and is pronounced in an open court to the public as a result of examination of a case ${ }^{19}$ In connection with this, there are three essential things to be considered by the judge in completing a case, that are justice, certainty, and benefit. All three of these should receive professional balanced attention, so that the judge's judgment may be useful in the life of the community, especially for the justice seeker. There are at least three functions of the judge in deciding a case according to law, namely: 1) applying the law; 2) finding the law, and 3) creating the law.

Applying the law implies that the judge merely provides the place of a legal event with the provisions of existing rules so that judges are referred to as mouth of the law. While finding the law means that the judge seeks to assemble between legal phenomenon on the one hand and the rule of law on the other and translates it and gives meaning to a law to be in contact with concrete legal phenomenon which are actually happening. ${ }^{20}$ This take into account that the law is not always readymade items, but must be found. In many respects the enforcement and enforcement of the law is not merely the application of law, but it is also often a legal discovery. ${ }^{21}$ According to jurists, because the activities of human life are innumerable, a law, however perfect and complete when it is made, always immediately after its deliberation will be perceived as lacking or there is a lack of clarity of meaning. ${ }^{22}$ Therefore, finding the law is a necessity in any existing legal system.

In contrast to the creating law, in this case, the judge is confronted with several conditions which, among others: 1) the existence of a vacuum or legal vacuum, there is no rule of law available to solve the legal problem encountered; (2) the existing law is unclear, for example because of inconsistencies

\footnotetext{
18 Pound, An Introduction to the Philosoph, 87-88.

19 Mukti Arto, Praktek Perkara Perdata pada Pengadilan Agama (Yogyakarta: Pustaka Pelajar, 2007), 251.

${ }^{20}$ Nessa, "Putusan Hakim Sebagai Wadah Pembaruan Hukum", in M. Sutomo and Ahmad Zaenal Fanani, Menggugat Stagnasi Pembaruan Hukum Islam di Indonesia (Yogyakarta: UII Press, 2018), 11-12.

21 Mertohadikusumo, Ilmu Hukum (Yogyakarta: Liberty, 1988), 136.

22 Syamsul Anwar, Metodologi Hukum Islam (Yogyakarta: UIN-SUKA Postgraduate Module, 2006), 13.
} 
between chapters one to another; (3) the existing law is obsolete as a result of changes occurring within the community so that judges have the authority to override the obsolete rules by creating new laws; and (4) the existing law is contrary to the sense of justice or public order. ${ }^{23}$

Basically, to make the judge's decision as a means of legal reform, then as a logical consequence the judges are required not only to be a mouthpiece of the constitution, but to be able to make legal finding. Therefore, the judge must have the expertise and courage in doing judicial activism include a series of knowledge, skills and personality. This will enable to encourage the judge to explore and find the values of living law in accordance with the rule of law as conceived by the sociological jurisprudence school, especially the Pound's concept mentioned above. Remembering, as affirmed by A. Qodry Azizy, it is very rare for judges to dare to do ijtihâd or attempt to make legal finding (istinbâth) in any decision. According to Azizy, at least there are three factors that become the base of some problems, they are: (1) the jud's distrust; (2) lack of knowledge; and (3) The Power of Legism in the Judges' Mindset. ${ }^{24}$

A judge is a person who has been destined to study all his life. Paul Scholten, renowned Dutch scholar, said that the judge's decision is a verdict of the mind and conscience. ${ }^{25}$ If less than it or a slight defect, then the verdict will be a painful torment for the sense of community justice. In this context, they require the annotation of the jurists in the decisions they made. In contrast, for jurists working in the field of law science, records and comments (annotations) regarding court decisions are also required. Prof. Hoetink once said in relation to this, "Alfa and Omega of jurisprudence is a fair judge's decision in concrete cases, from there he departs and there is also his estuary. Otherwise, the scientific work of discipline of the law would be a futile job and would only torture the mind. ${ }^{26}$ Therefore, the judges are graduates of the Faculty of Law and in his duties as a judge he should not leave the corridor from his legal scholarly sources. In contrast, for the academic community of law, the judge's decision is a feedback for coaching and further development of law science. Moreover, it is important to drive the perception of judge's decision as a tool of social engineering. Making the judge's decision as a tool of social engineering, according to Ahmad Ali, has the potential as a balance between the stiffness and legal certainty of the written with the passage of the law from the dynamic social development rhythm. Legal inaction, in this case, can be offset by elegant character of judge made law making it easier to adapt to the needs of society. ${ }^{27}$ In the theory of legal sociology, as A.P. Craabree LLB. said, that "law is the clothes of living body of society". The law is the clothing of society that must fit the size and stitches to the needs of the community. The law follows the needs of society and reflects the benefits. ${ }^{28}$

Applications of the paradigm can be seen for example in the case of joint treasure, and the explanation of Article 55 paragraph (2) on Sharia Economics which has been canceled by the Constitutional Court. Of course in this case, the judges do not have to decide on the basis of the

\footnotetext{
${ }^{23}$ Nessa, "Putusan Hakim Sebagai Wadah Pembaruan Hukum., 12.

24 A. Qadri Azizy, Eklektisisme Hukum Nasional, Kompetisi Antara Hukum Islam dan Hukum Umum (Yogyakarta: Gama Media, 2002), 173.

25 Jaako Husa, "Law and Context: Scholten's Open System of Law and Legal Harmonisation", Preprint, edition 2, Amsterdam: Digital Paul Scholten Project. Sep 2014. http://www.paulscholten.eu/research/article/law-and-context/

26 Arifin, "Segi Hukum yang Terlupakan", Prologue in Satria Effendi M. Zein, Problematika Hukum Keluarga Islam, xxiii.

27 Nessa, "Putusan Hakim Sebagai Wadah Pembaruan Hukum, 15.

28 Abdul Manan, "Prologue", in M. Sutomo dan Ahmad Zaenal Fanani, Menggugat Stagnasi Pembaruan Hukum Islam, xiii-xiv. See also Dadan Muttaqin, Peradilan Agama dan Kompilasi Hukum Islam dalam Tata Hukum Indonesia (Yogyakarta: UII Press, 1999 ), 80.
} 
sound of the contract which includes clauses in case of dispute, then resolved in the District Court with reference to Article 1338 BW, whereas the explanation of Article 55 paragraph (2) of Law No. 21/2008 on Sharia Banking has been declared the Constitutional Court in its decree No. 93 / PUU-X/2012 no longer have the power of law. In this context, the role of the judge's decision finds its vital momentum. The role of judges' decision will become increasingly significant as legal reform agents in Indonesia. Therefore, judges are required to do the work of legal finding. The professional work of the judges contained in their decisions shall not be corrected by non-judicial authorities. In this case, independence and freedom of judges are guaranteed in Article 24 paragraph (1) of the 1945 Constitution which mandates the independence of judges from any party's intervention and guarantees judicial power as an independent power to administer justice in order to enforce law and justice. In addition, judges are the only apparatus that is granted the right of judicial immunity to decide cases. The right of immunity is a form of impunity that protects the judges from lawsuits over the actions they perform in performing their duties. In this context, the Supreme Court will not take action on the recommendation of the Judicial Commission when it is related to technical judicial. ${ }^{29}$

The problem is, whether the freedom and immunity rights possessed by the judge, it will make the judge tend to ignore the values of professional ethics so that the right will actually trigger a problem of injustice judge in trying cases that lead to unprofessional conduct? In this issue, Bagir Manan stated that the judge's position as the creator implements the law. He exemplified in civil cases regarding the determination of interest rates on loans. As has been followed in jurisprudence so far, that every treaty is a law for the party who made it based on Article 1338 BW. Facing this case will certainly be a dilemma for a judge. The dilemma between deciding cases based on Article 1338 will certainly leave a variety of issues, or whether he will release the article or decide the case by speaking with finding his own law. Literally, when a judge confronts a covenant that is not in harmony with the ideals of justice, such as a $10 \%$ lending rate a month, then the agreement is reinforced by being made before a notary. Does the judge then give a verdict to strengthen it? If this is the way in which the judge proceeds, then according to justice the law is true, but according to the taste of justice is not true. In this case the role of justice felt by the judge was very influential.

Though up to now Indonesia recognizes legal pluralism, that is, the customary law system, the Islamic legal system and the Western system, but it is no exaggeration to say that Islamic law in Indonesia is a living law, aspects of certain arrangements, it is not or has not been made a positive law by the State. Many questions and concerns about the law in society proposed to scholars and religious organizations such as NU, Muhamadiyah and Indonesian Council of Ulama (MUI), should be seen and perceived as a sign that Islamic law is a living law in society. ${ }^{30}$

\section{b. Judge's Decision and Islamic Law Reform}

The judge can basically function as a reformer of the law. There are several ways that can be done in relation to this, among others, first, exploring laws that are not expressly contained in the applicable legislation and the values of justice that live in the community. Second, to follow the norms and rules of the unwritten law developed in the community (living law) at the same time pay attention to the values of justice. Third, understand the legal norms and rules of justice that thrive in

29 Nessa, "Putusan Hakim Sebagai Wadah Pembaruan Hukum," 17.

30 Said Aqil Munawwar, Hukum Islam dan Pluralitas Sosial (Jakarta: Paramadina, 2004), 29. 
everyday life. ${ }^{31}$

Roscoe Pound in his conception of law as a tool of social engineering, as described in the previous discussion, stated that law can play a significant role in the reform process. The experience of the United States, in relation to this, may be a reference. In the United States, especially after the new deal began in the 1930s, law can serve as a vehicle for realizing social changes. The role of the law in the form of decisions of the United States Supreme Court in realizing equal rights for all its black people can be the most impressive example of the progressive role that law can play in society. ${ }^{32}$ Pound's concept is inseparable from the paradigm of judge made law as the main source of rule of law of the United States that in fact follow the common law system. Therefore, the "law" in the concept of law as a tool of social engineering is a law made by a judge. In Pound's view, the judge plays a role as the agent of social change. This is of course different from the existing culture in Indonesia, where the source of the rule of law in the reform of national law is the legislation.

However, this approach does not mean ignoring the judge's decision or judge's role in community reform at all. That the judge's decision, as expressed by Bagir Manan, plays a very significant role in policy or legal politics which always incorporates the court as one of the objects of legal reform..$^{33}$ Based on Bagir Manan's conception, it can be understood how the role of the judge's decision is very important to ensure the unity of law in resolving the dispute faced by the judge. While the coaching and development of the judge's decision lies with the highest judicial body which in this case becomes the authority of the Supreme Court. Thus, it begins with the judge's decision (the jurisprudence) made by this supreme judge which in turn determines the direction to which the law is to be brought. Moreover, how great the role of Supreme Court justices as a legal reformer in determining the dynamics of jurisprudence is expected to create a standard law that contains common basic ideas that have double dimension at once, which is able to cover the values that live in the community on one side, and global values on the other hand, so as to create a rational, practical, and actual legal character towards the maturity of law. ${ }^{34}$ Based on this framework, there is no doubt that jurisprudence is one of the sources of the law in addition to the Constitution, custom, trace and doctrine or the opinion of leading jurists. At the very least, the meaning and position of source of jurisprudence law is obvious urgency because it can be used as a reference in several important matters, such as: (1) the formation of laws; 2) taking a decision on the same matters by other judges on matters that have not been regulated or not yet found to be legal; and 3) develop jurisprudence through judicial decision. ${ }^{35}$

In addition, it should also be understood that a legal system is basically built by some supporting elements. Friedman mentioned that there are three interrelated elements in the legal system. These elements are, legal structure, legal substance, and legal culture. ${ }^{36}$ The three elements are in a process of interaction with each other and form a totality called the legal system. In the national context, Indonesian law basically requires the development of religious life and religious law in the life of national law. Major Guidelines of State Policy (GBHN) in the field of law requires the creation of a

\footnotetext{
31 Nessa, "Putusan Hakim Sebagai Wadah Pembaruan Hukum...," 21.

32 Mochtar Kusumaatmajda, Konsep-Konsep Hukum dalam Pembangunan (Bandung: Alumni, 2002), 13-15.

33 Bagir Manan, "Hakim Sebagai Pembaru Hukum," in Varia Peradilan No. 254, Januari (2007), 6.

34 Nessa, "Putusan Hakim Sebagai Wadah Pembaruan Hukum," 22-23.

35 Ibid., 23.

36 Lawrence M. Friedman, The Legal Sistem (New York: Russel Sage Foundation, 1975), 131.
} 
new law in Indonesia in accordance with the ideals of Pancasila and the 1945 Constitution, as well as serving the national interest.

From the policy direction can be noted some things as follows: (1) the source of national law is not single. According to Qadry Azizy, there are three sources of national law: religion, customary law and Western law ${ }^{37}$; (2) 2) still exist, even many national laws are colonial inheritance, so it is irrelevant to the current era of reform. Among the colonial heritage are the Book of the Criminal Code (KUH Pidana) and the Code of Civil Law (KUH Perdata); and (3) 3) legal renewal is done through legislation, a process to produce laws and regulations that are pursued procedurally and democratically.

The problem of the existence of Islamic law, in the national context, becomes necessary to be discussed for two reasons. First, from the quantitative side, Muslims constitute the majority in the composition of the Indonesian population, so it is too risky if their interests are not accommodated or neglected. Borrowing Durkheim's conception that religion has a role in society as a unifying, binding and preserving force. But it can also be a scattering force when it is not followed by all or most members of society. ${ }^{38}$ In other words, that religion whose legal doctrine is to be national law should be adopted by most of the society. Such requirements are important, politically as an adhesive factor, as well as sociologically religious can be viewed as living laws. ${ }^{39}$ Secondly, this is a general reason, in the Islamic tradition, law is an aspect that cannot be separated from the lives of its adherents. So it is natural that any Western writer would dare to say: “...it would not be exaggeration to characterize Islamic culture as a legal culture." 40 In almost the same view, Clifford Geertz saw that a legal norm cannot be separated from the context of the facts and local knowledge of the community ${ }^{41}$ In the context of Indonesia, this statement has been proven by a history where Islamic law has long been one of the systems governing the lives of Muslim societies. ${ }^{42}$

Furthermore, to see the role of Islamic law in the development of national law, there are several phenomena that can be found in practice. First, Islamic law plays a role in filling the legal void in positive law. In this case Islamic law is imposed by the State as a positive law for Muslims. Second, Islamic law plays role as a source of value that can contribute to the rule of law made. Since the rule of law is general, regardless of religious differences, the universal values of Islamic law may apply to all citizens. In connection with this, Ismail Sunny illustrates the politics of law as a process of acceptance of Islamic law described his position into two periods, namely: First, the period of persuasive source where every Muslim is believed to accept the enforcement of Islamic law. Second, the period of authority source where every Muslim believes that Islamic law has the power to be

37 Azizy. Eklektisisme Hukum Nasional, 174.

38 Jesús Romero Moňivas, "Science and Religion in The Sociology of Emile Durkheim," European Journal of Science and Theology, Vol. 3, No. 1, March (2007): 17-30. Compare with Elizabeth K. Noitingham, Agama dan Masyarakat, cet. Ke-6, trans. Abdul Muis Naharong (Jakarta: Raja Grafindo, 1996), 42.

39 Ahmad Syafi'i SJ, "Globalitas dan Lokalitas Hukum Islam: Menggagas Hukum Islam yang Akomodatif -Transformatif dalam Konteks Legal Pluralism di Indonesia," Al-Dabiya Jurnal Kebudayaan dan Keagamaan, Vo. 2, No. 2, Juli-Desember (2007), 112-113.

40 Wael B. Hallaq, A History of Islamic Legal Theories (Cambridge: Cambridge University Press, 1997), 209.

41 Clifford Geertz, Local Knowledge: Further Essays in Interpretative Anthropology (New York: NY: Basic Books, 1983). See also Geertz, The Interpretation of Culture: Selected Essays (New York: NY: Basic Books, 1973). Compare with Hans Schoenmakers, The Power of Culture: A Short History of Anthropological Theory About Culture and Power (University of Groningen: Globalization Studies Groningen, 2012), 67-72.

42 Read more, for example, Simuh, Islam dan Pergumulan Budaya Jawa, (Jakarta: Teraju, 2003), 70; also M. Arskal Salim GP, "Politik Hukum Pidana Islam di Indonesia: Eksistensi Historis, Kontribusi Fungsional dan Prospek Masa Depan" in Pidana Islam di Indonesia: Peluang, Prospek, dan Tantangan (Jakarta: Pustaka Firdaus, 2001), 257-58. 
held. ${ }^{43}$ In other words, Islamic law can apply in a formal juridical manner when codified in national legislation.

\section{Conclusion}

Making judge's decision or jurisprudence as a means of legal reform is a necessity. This can be realized through the progressive paradigm of a judge. The presence of a progressive legal paradigm is very important in the context of law enforcement. With this paradigm, is expected to bear the figure of a progressive type of judge as well. The judge is a central figure in the judicial process. A fair judge's ruling will be the peak of wisdom for the settlement of legal issues that occur in the life of the nation and state. Therefore, in addition to being a State official exercising judicial powers, having a noble position with a noble duty, the judge is also required to play his role as a legal reformer in performing his judicial duties of applying, finding and creating the law.

Reflecting on the sociological concepts of jurisprudence as described earlier, particularly the idea put forward by Roscoe Pound, how the role judges should play as creators of law-making must be based on the principles of justice because judgments have adequate social, political and cultural impacts which are quite extensive. Nevertheless, placing judges as law makers is not always easy, as judges are only one of the practical legal bearers who in maintaining their independence and integrity are always shrouded in the interests of judges and external interests that are not solely aimed at the legal objectives of justice, benefit and certainty.

The legal philosophy of the school of sociological jurisprudence offers a holistic understanding and perspective of law, that is, the applied law must pay attention to the values and the living law and local wisdom of society. This conception at the same time provides a basis for the urgency of interaction between law and society. Therefore, the law must be compared to the community to fulfill the benefit of the law and the welfare of society. This holistic understanding of law will ultimately be able to unify the law and society as its sociological basis. For this reason, the study of the legal philosophy of Roscoe Pound with his school of sociological jurisprudence for the development of jurisprudence including Islamic law is very reasonable and urgent to do.

\section{Bibilography}

Anwar, Syamsul. Metodologi Hukum Islam. Yogyakarta: UIN-SUKA Postgraduate Module, 2006.

Arifin, Bustanul. "Segi Hukum yang Terlupakan." Prologue in Satria Effendi M. Zein. Problematika Huum Keluarga Islam Kontemporer: Analisis Yurisprudensi dengan Pendekatan Ushuliyah. Jakarta: Prenada Media Group, 2010.

Arto, Mukti. Praktek Perkara Perdata pada Pengadilan Agama. Yogyakarta: Pustaka Pelajar, 2007.

Azizy, A. Qadry. Eklektisisme Hukum Nasional, Kompetisi Antara Hukum Islam dan Hukum Umum. Yogyakarta: Gama Media, 2002.

Bodenheimer, Edgar. Jurisprudence: The Philosophy and Method of The Law, Revised Edition. Cambridge, London: Harvard University Press, 1978.

\footnotetext{
43 Ismail Sunny, “Tradisi dan Inovasi Keislaman di Indonesia dalam Bidang Hukum Islam”, in Bunga Rampai Peradilan Islam di Indonesia (Bandung: Ulul Albab Press, 1997), 40-43.
} 
Chinhengo, Austin M. Essential Jurisprudence, Second Edition. London: Cavendish Publishing Limited, 2000.

Dias, R.W.M. Jurisprudence. London: Butterworths, 1976.

Friedman, Lawrence M. The Legal System. New York: Russel Sage Foundation, 1975.

Friedman, Lawrence M. Legal Theory. $4^{\text {Th }}$ Edition. London: Stevens \& Sons Limited, 1960.

Gardner, James A. “The Sociological Jurisprudence of Roscou Pound (Part I)." Villanova Law Review, Vol. 7, No. 1, Art. 1 (1961): 1-26.

Geertz, Clifford. Local Knowledge: Further Essays in Interpretative Anthropology. New York: NY: Basic Books, 1983.

Geertz. The Interpretation of Culture: Selected Essays. New York: NY: Basic Books, 1973.

Hallaq, Wael B. A History of Islamic Legal Theories. Cambridge: Cambridge University Press, 1997.

Husa, Jaako. "Law and Context: Scholten's Open System of Law and Legal Harmonisation." Preprint, edition 2, Amsterdam: Digital Paul Scholten Project. Sep 2014. http://www.paulscholten.eu/ research/article/law-and-context/

Kristiana, Yudi "Rekonstruksi Birokrasi Kejaksaan dengan Pendekatan Hukum Progresif, Studi Penyelidikan, Penyidikan, dan Penuntunan Tindak Pidana Korupsi.” Disertasi. Semarang: PDIH UNDIP, 2007.

Kuhn, Thomas S. The Structure of Scientific Revolution, 2nd Edition. Chicago: The University of Chicago Press, 1970.

Kuhn, Thomas S. “The Structure of Scientific Revolution.” International Encyclopedia of Unified Science, Vol. 2, No. 2 (1970): 1-174.

Kusumaatmajda, Mochtar. Konsep-Konsep Hukum dalam Pembangunan. Bandung: Alumni, 2002.

Langone, Richard. "The Science of Sociological Jurisprudence as a Methodology For Legal Analysis." Touro Law Review, Vol. 17, No. 4, Art. 5, March (2015): 768-800.

Manan, Bagir. “Hakim Sebagai Pembaru Hukum.” in Varia Peradilan, No. 254, Januari (2007).

McManaman, Linus J. “Social Engineering: The Legal Philosophy of Roscoe Pound." St. John Law Review, Vol. 33, No. 1, Art. 1, December (1958): 1-47.

Mertohadikusumo. Ilmu Hukum. Yogyakarta: Liberty, 1988.

Moňivas, Jesús Romero. "Science and Religion in The Sociology of Emile Durkheim." European Journal of Science and Theology. Vol. 3, No. 1, March (2007): 17-30.

Munawwar, Said Aqil. Hukum Islam dan Pluralitas Sosial. Jakarta: Paramadina, 2004.

Murphy, Jeffrie G. and Jules L. Coleman. Philosophy of Law: An Introduction to Jurisprudence, Revised Edition. San Francisco, London: Westview Press, 1990.

Muttaqin, Dadan. Peradilan Agama dan Kompilasi Hukum Islam dalam Tata Hukum Indonesia. Yogyakarta: UII Press, 1999.

Nessa, Rum. "Putusan Hakim Sebagai Wadah Pembaruan Hukum.” In M. Sutomo and Ahmad Zaenal Fanani. Menggugat Stagnasi Pembaruan Hukum Islam di Indonesia. Yogyakarta: UII Press, 2018.

Noitingham, Elizabeth K. Agama dan Masyarakat. cet. Ke-6, trans. Abdul Muis Naharong. Jakarta: Raja Grafindo, 1996. 
Pareja, Harold P. "Sociological Jurisprudence: It's History, Applications, And Trends." SDSSU Multidisciplinary Research Journal, Vo. 2 No. 1, Jan-June (2014): 61-69.

Posner, Richard A. “The Role of The Judge in The Twenty-First Century.” Boston University Law Review, Vol. 86. (2006): 1049-1068.

Pound, Roscoe. Pound. Social Control through Law. New Haven, 1942.

Pound, Roscoe. Justice According to Law. New Haven, 1951.

Pound, Roscoe. An Introduction to The Philosophy of Law. New Brunswick \& London: Transaction Publishers, 1999.

Pound, Roscoe. "In My Philosophy of Law.” In Ervin H. Pollack. Jurisprudence: Principles and Applications. The Ohio State University Press, 1979.

Pound, Roscoe. "The Scope and Purpose of the Sociological Jurisprudence." In Harvard Law Review, Vol. 25 (1912), 513-516.

Pound, Roscoe. "Spirit of the Common Law" and "A Theory of Social Interests." In Papers and Proceedings of the American Sociological Society. Quoted from Hall. Readings in Jurisprudence, 238 et seq.

Pound, Roscoe. Interpretation of Legal History. USA: Holmes Beach, Florida, 1986.

Pound, Roscoe. The Ideal Element in Law. Calcutta: Liberty Fund \& Indianapolis, 1958.

Radbruch, Gustav. Legal Philosophy. (First Publ., 1932), trans. Kurt Wilk, in: The Legal Philosophy of Lask, Radbruch, and Dabin. Cambridge, Mass: Harvard University Press, 1950.

Rahardjo, Sajtipto. "Hukum Progresif: Hukum yang Membebaskan.” Jurnal Hukum Progresif. Vol. 1, No. 1, April (2005).

Rahardjo, Sajtipto. Hukum dan Perubahan Sosial. Bandung: Alumni, 1979.

Rahardjo, Sajtipto. Penegakan Hukum Progresif. Jakarta: Penerbit Buku Kompas, 2010.

RI, Mahkamah Agung. Cetak Biru Pembaruan Peradilan 2010-2035. Jakarta: MA RI, 2010.

Riswandi, Budi Agus dan M. Syamsuddin. Hak Kekayaan Intelektual dan Budaya Hukum. Jakarta: Raja Grafindo, 2009.

Salim GP, M. Arskal. "Politik Hukum Pidana Islam di Indonesia: Eksistensi Historis, Kontribusi Fungsional dan Prospek Masa Depan." In Pidana Islam di Indonesia:Peluang, Prospek, dan Tantangan. Jakarta: Pustaka Firdaus, 2001.

Schoenmakers, Hans. The Power of Culture: A Short History of Anthropological Theory About Culture and Power. University of Groningen: Globalization Studies Groningen, 2012.

Shidarta. "Filosofi Penalaran Hukum Hakim Konstitusi dalam Masa Transisi Konstitusionalitas." Jurnal Hukum Jentera. Edisi 11 tahun III, Januari-Maret (2006).

Shioshivili, Irma. "General Antecedents of Philosophy by Gustav Radbruch." Bulletin of The Geogrian National Academy of Science, Vol. 11, No. 2 (2017): 128-135.

Simuh. Islam dan Pergumulan Budaya Jawa. Jakarta: Teraju, 2003.

Sunny, Ismail. “Tradisi dan Inovasi Keislaman di Indonesia dalam Bidang Hukum Islam”, in Bunga Rampai Peradilan Islam di Indonesia. Bandung: Ulul Albab Press, 1997. 
Syafi'i SJ, Ahmad. “Globalitas dan Lokalitas Hukum Islam: Menggagas Hukum Islam yang Akomodatif

-Transformatif dalam Konteks Legal Pluralism di Indonesia." Al-Dabiya Jurnal Kebudayaan dan Keagamaan, Vo. 2, No. 2, Juli-Desember (2007), 112-113.

Syamsuddin, M.“Kecenderungan Paradigma Berpikir Hakim dalam Memutuskan Korupsi." Jurnal Media Hukum Fakultas Hukum. Desember (2008), 90-97.

Tamanaha, Brian Z. “The Third Pillar of Jurisprudence: Social Legal Theory.” William \& Mary Law Review, Vol. 56, No. 6, Art. 6 (2015): 2235-2277.

Wolf, Erik. "Revolution or Evolution in Gustav Radbruch's Legal Philosophy." Natural Law Forum, Art. 25 (1958): 1-23. 
